\title{
Electric-solar boats: an option for sustainable river transportation in the Ecuadorian Amazon
}

\author{
F. Guamán ${ }^{1}$, J. Ordoñez ${ }^{1}$, J. L. Espinoza ${ }^{1}$ \& J. Jara-Alvear ${ }^{2}$ \\ ${ }^{I}$ Department of Electrical and Electronic Engineering, \\ University of Cuenca, Ecuador \\ ${ }^{2}$ Centre for Development Research, University of Bonn, Germany
}

\begin{abstract}
Accessibility to the Ecuadorian Amazonian region is critical due to its high level of isolation and lack of infrastructure, which restricts people's mobility to long walks, river boats, small planes or a combination of them. Building roads in the Amazon region will expedite accessibility and socio-economic development; however it has a high environmental impact. Finding alternative solutions for transportation without endangering the Amazon ecosystem is a challenge for sustainability. Using the extensive network of rivers in the Amazon is becoming a potential solution for transportation. However, this mean of mobility faces its own drawbacks related to fuel cost and availability, environmental impacts and fuel smuggling through the border impacting national security. Electric canoes coupled with renewable energy systems represent an alternative that has been successfully applied in several parts of the world, including Galapagos-Ecuador. Therefore, this paper aims to present a technical-economic analysis of solar canoes to be used in rivers of the southern part of the Ecuadorian Amazonian where more than 500 indigenous families live. These communities now have electricity, through individual photovoltaic systems from the "Yatsa Ii Etsari" project developed by the local utility. The results show that solar canoes are a technical and economical option for autonomous navigation up to 4 hours, representing a sustainable alternative for river transportation in the Ecuadorian Amazon.
\end{abstract}

Keywords: electric solar boats, Amazon, photovoltaic, river transport. 


\section{Introduction}

Accessibility to the Ecuadorian Amazonian region is critical due to its high level of isolation and lack of infrastructure, which restricts people's mobility to long walks, river boats, small planes or a combination of them. Building roads in the Amazon region will expedite accessibility and socio-economic growth. However, high environmental impacts and high construction costs impede roads' full development. Therefore, finding alternative solutions for transportation without endangering the Amazon ecosystem is an urgent challenge towards sustainability. River transport in the Ecuadorian Amazon is one of the primary means of mobility in places where there are no roads (Jara-Alvear et al. [1]). So far, the rivers have enabled the navigation of small boats with outboard motors for moving people and goods. However, this mode of transportation causes significant environmental problems. The main negative impacts are the generation of greenhouse gases - GHG, lubricants and fuel spills in rivers as well as the felling of large trees for manufacturing wooden canoes.

The described situation leads to the conclusion that the current model of transportation in the Amazon Rivers is unsustainable. Many of these problems can be mitigated by replacing the gasoline-outboard motor by electric propulsion systems. The application of these systems is not new. In 1839 Moritz von Jacobi Herman built one of the first electric boats (Morachevskii [2]) and today these systems have made significant progress worldwide, as demonstrated by transatlantic crossings [3, 4]. Moreover, in 2013, the first Ecuadorian solarelectric boat was built and demonstrated its usability in the Galapagos Islands as a means for environmental education and sustainable tourism (as shown by JaraAlvear et al. [5]).

All in all, electric propulsion represents an alternative for traditional outboard motor in order to tackle the problem of exhaust emissions, fossil fuel spill on rivers, and noise in fragile ecosystems. On the other hand, the limitation for electric boats are the high up-front cost of technology, reduced travel autonomy and low speed, all limited mainly by existing storage technology (Del Pizzo et al. [6]). Nevertheless, coupling electric boats with on-board renewable energy generation and charging stations along the travel route could potentially help to surpass these barriers and facilitate their adoption in isolated areas like the Amazon region.

\section{Objective}

The overall aim of this paper is to present the results of a techno-economic study developed to assess the feasibility of replacing traditional outboard motors used in rivers of the province of Morona Santiago, in the Southern part of the Ecuadorian Amazon, for electric outboards coupled with solar energy systems.

To achieve this goal, the following specific objectives were proposed:

- To study local conditions for river transportation through field visits.

- To propose a design for a solar canoe adapted to the Amazon Rivers. 
- To perform an economic analysis of replacing traditional canoes for solar canoes.

\section{Methodology}

\subsection{Field research}

The case study area is located in the province of Morona Santiago, Ecuador, specifically within the main river accesses to indigenous communities of that region (Figure 1). Since 2010 this area was electrified by the local utility, Centrosur S.A, under the initiative called Yatsa Ii Etsari, providing individual Photovoltaic Systems - PVS to isolated indigenous families. By the end of 2014, the project has over 3,000 users of which about 500 families are settled on the banks of the rivers under analysis. This area was chosen since solar canoes represents an ideal solution to support logistics of the utility staff who visit periodically the area to perform maintenance task, which is a critical factor that threaten the survival of the project as described by Jara-Alvear et al. [1]. Also these solar systems could potentially be used to recharge the batteries of solar canoes.

The first part of the work consisted of a field trip to the main rivers: Morona, Cangaime, Macuma and Magosiza (Figure 1) for data collection of travel conditions in order to determine the design parameters of the solar canoes, which corresponds the second specific goal of the study. The final objective of the study is to perform the techno-economic analysis of the proposed alternative.

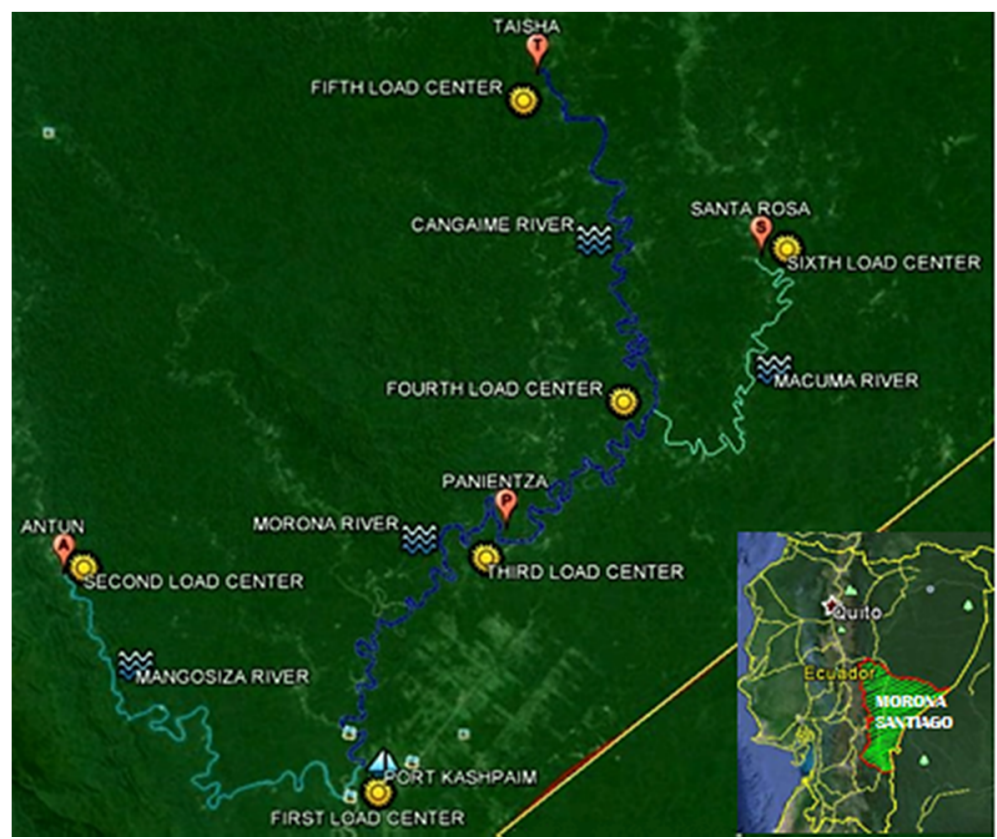

Figure 1: Map of the study area. 


\subsection{Design concept}

The proposed configuration for the electric boat (Figure 2) is based on the design of [5], since it has demonstrated the viability to displace up to 4 tones which is the expected weight to be carried by the existing canoes in the study area. The design includes an electric outboard motor (direct current) coupled with a bank of electrochemical batteries (lithium or lead-acid); and, a photovoltaic system PV on board to recharge the batteries. In addition, photovoltaic recharge stations located along the routes are considered (Figure 1).

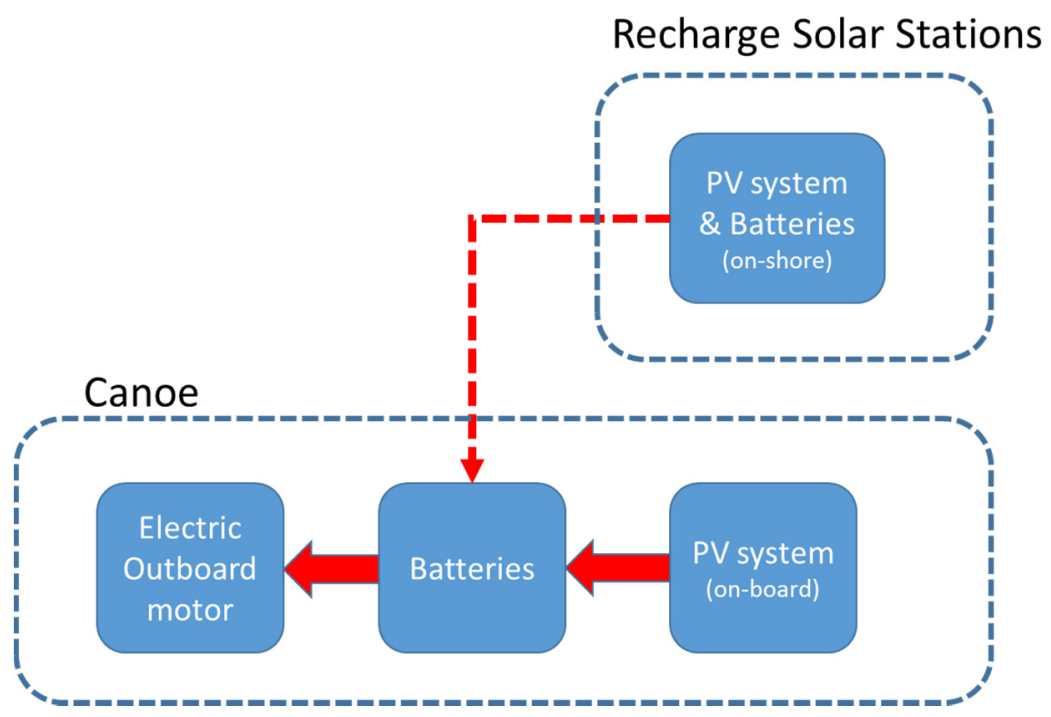

Figure 2: Design concept solar canoes (adapted from [5]).

\subsection{Sizing}

The following sizing methodology is based on both the experience of [5] and related literature review $[7,8]$ in order to size small scale electro-solar displacement boats. Although there are two types of boat (displacement and planning), displacement boats travel at speeds below 12 knots.

Step 1: The design speed is a critical factor since the faster the canoe the higher its energy consumption. Moreover, speed influences the boat resistance to propulsion. In a displacement boats the maximum speed or hull speed can be determine using eqn. (1), where $\mathrm{V}$ is the hull speed $(\mathrm{km} / \mathrm{h})$, LWL is the waterline length of the boat (m), and $\mathrm{R}$ is the degree of speed according to Gutelle [8]. For the designing process it is recommended to select a speed lower than the hull speed.

$$
V=R * 1.85 * \sqrt{L W L}
$$


Step 2: The canoe has to overcome resistance to propulsion which is influenced by its speed, displacement (weight), and hull form Bertram [7]. Therefore resistance estimation is complex and there are different methods to calculate it $[7,8]$. For the purpose of this study, eqn. (2) is used to estimate the value of the total resistance $\mathrm{Rt}$, which is the result of multiplying the resistance to advance Rs per the total weight of the system $\mathrm{W}$. The resistance to advancement Rs takes values depending on the degree of speed R (Table 1), which is selected according to the average speed required for design.

$$
R t=R s * W
$$

Table 1: $\quad \mathrm{R}$ and Rs values for displacement boats [8].

\begin{tabular}{|c|c|c|c|c|c|c|c|}
\hline $\mathbf{R}$ & 1.34 & 1.4 & 1.6 & 1.8 & 2 & 2.2 & 2.4 \\
\hline Rs (daN*/ton) & 5 & 6 & 8 & 12 & 16 & 22 & 31.5 \\
\hline$* 1$ daN (dekanewton) $=$ & $=1.0197$ kilogram-force [kgf].
\end{tabular}

Step 3 Propeller power: Knowing the speed and resistance the propeller power $\mathrm{Pp}(\mathrm{kW})$ required to displace the canoe at the desirable speed can be calculated with eqn (3) including a security factor (Bertram [7]). Where Rt is the total resistance per ton $(\mathrm{kgf}), \mathrm{V}$ is the speed $(\mathrm{km} / \mathrm{h})$.

$$
P p=0,007 * R t * V
$$

Step 4 Input power: The propeller power does not include the efficiency of: the propeller $(\eta p)$, shafts power $(\eta s)$, electronic controls and electric motor $(\eta e)$. Therefore, the input power $(\mathrm{Pi})$ required is:

$$
P i=\frac{P p}{\eta p * \eta s * \eta e}
$$

Nowadays manufacturers of electric outboards have reached a maximum efficiency for the complete drive train of $56 \%$ which includes $\eta p$, $\eta s$, and $\eta e$ (TORQEEDO [9]).

Step 5 Energy consumption: Based on the power required at a desirable speed and the time of traveling ( $\mathrm{t}$ ), it is possible to calculate the energy required (E) for batteries storage including a security factor (SF) as presented in eqn. (5).

$$
E=P i * t * S F
$$

Step 6 Battery size: Knowing the energy consumption it is possible to determine the size (Ah) of the battery bank (B) in function of the voltage of the electric outboard motor $(\mathrm{Vt})$ and maximum deep of discharge of the battery (Dd) as shown in eqn. (6). At the end, the number of batteries and its interconnection will depend on the selected model, type of battery (lithium or lead-acid) and available space in the boat.

$$
B=\frac{E}{D d * V t}
$$

Step 7 Photovoltaic generator: The size $(\mathrm{kWp})$ of the solar PV panels is estimated considering the energy consumption (E), the monthly lowest average 
solar radiation during the year (February) in the study area $(\mathrm{kWh} / \mathrm{sqm} /$ day) and the average efficiency of the complete photovoltaic generator (PVeff) (CONELEC [10]). Then the size of the PV generator is:

$$
S=\frac{E}{P \operatorname{Peff} * S R}
$$

If the energy consumption is too high, is probable that the solar panels area is bigger than the available area in the boat (see Table 3). In this sense, the study proposes the option of solar recharge stations on strategic locations along the travel route. It is important to highlight that the energy consumption could be reduced drastically if lower travel speeds are selected during the design (JaraAlvear et al. [5]).

\section{Results}

\subsection{Data collection}

From field research the main origin and travel destinations were identified as well as the average speed and travel time. This data was obtained using a GPS and chronometer (Table 2). It is important to note that routes $1-4 ; 2-5 ; 3-6$ represent a round tour whereas route 7 represents the distance between two charging points, with an average travel time of 3 hours (Figure 1).

Table 2: $\quad$ Main river routes, Morona Santiago-Ecuador.

\begin{tabular}{|c|c|c|c|c|c|c|}
\hline $\begin{array}{c}\text { Route } \\
\text { number }\end{array}$ & From & To & $\begin{array}{c}\text { Name } \\
\text { of river }\end{array}$ & $\begin{array}{c}\text { Time } \\
\text { (hour) }\end{array}$ & $\begin{array}{l}\text { Average } \\
\text { speed } \\
(\mathbf{k m} / \mathbf{h})\end{array}$ & $\begin{array}{c}\text { Distance } \\
(\mathbf{K m})\end{array}$ \\
\hline 1 & \multirow{3}{*}{ Kashpaim } & Antun & $\begin{array}{c}\text { Morona- } \\
\text { Mangosiza }\end{array}$ & 4 & 9 & 42 \\
\hline 2 & & Taisha & $\begin{array}{c}\text { Morona- } \\
\text { Cangaime }\end{array}$ & 9 & 9 & 92 \\
\hline 3 & & Santa Rosa & $\begin{array}{l}\text { Morona- } \\
\text { Macuma }\end{array}$ & 9 & 9 & 90 \\
\hline 4 & Antun & \multirow{3}{*}{ Kashpaim } & $\begin{array}{l}\text { Mangosiza- } \\
\text { Morona }\end{array}$ & 4 & 11 & 42 \\
\hline 5 & Taisha & & $\begin{array}{l}\text { Cangaime- } \\
\text { Morona }\end{array}$ & 9 & 11 & 92 \\
\hline 6 & Santa Rosa & & $\begin{array}{c}\text { Macuma- } \\
\text { Morona }\end{array}$ & 9 & 11 & 90 \\
\hline $\begin{array}{l}7 \text { (charge } \\
\text { center) }\end{array}$ & Kashpaim & Panientza & Morona & 3 & 9 & 30 \\
\hline
\end{tabular}

There are 45 canoes that travel the mentioned routes all year around. Based on 25 interviews, it was found that typical canoes have a LWL of 12 meters, an average displacement at full load of $1400 \mathrm{~kg}$, and use gasoline outboard motors of 13 Hp (Figure 3). 


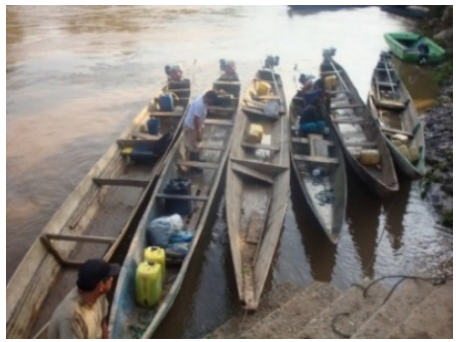

(a)

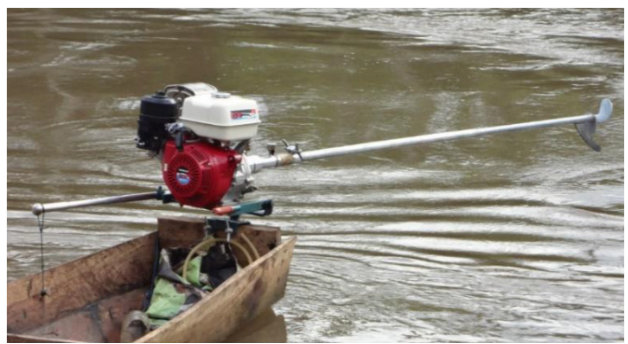

(b)

Figure 3: (a) Traditional canoes and (b) traditional outboard motor "pequepeque".

\subsection{Solar canoes configuration}

Based on the methodology described in 3.3 and using the data collected in 4.1, the configuration of an electric 12 meter-canoe for each representative route is described in Table 3, taking into account that routes 1,3 , and 7 correspond to 4 , 9 , and 3 hours of travel time, respectively.

The weight of the equipment is a critical factor during the design phase. For example, route 1 could use either 6 batteries (La) or 5 batteries (Li). The selection of the type of battery is determinant to calculate the equipment weight to be carried by the boat. Therefore the total weight of equipment (Table 3) has been estimated by considering the main system components (Table 4). The total cost of the solar canoe is also estimated.

Table 3: $\quad$ Electric 12-meter canoe configuration for each route.

\begin{tabular}{|c|c|c|c|c|c|c|c|}
\hline \multirow[t]{2}{*}{$\begin{array}{c}\text { Route } \\
\text { number }\end{array}$} & \multirow{2}{*}{$\begin{array}{c}\text { Power } \\
\text { electric } \\
\text { outboar } \\
\text { d } \\
(\mathbf{k W})\end{array}$} & \multicolumn{2}{|c|}{$\begin{array}{c}\text { Capacity } \\
\text { battery bank } \\
(\mathbf{k W h})\end{array}$} & \multicolumn{2}{|c|}{$\begin{array}{c}\text { Solar generation } \\
\text { (PVS) }\end{array}$} & \multicolumn{2}{|c|}{$\begin{array}{c}\text { Total weight of } \\
\text { equipment (Ton) } \\
\text { PVS and boat are not } \\
\text { considered }\end{array}$} \\
\hline & & La* & $\mathbf{L i}^{* * *}$ & $\begin{array}{c}\mathbf{k W p} \\
\text { (required) }\end{array}$ & $\begin{array}{c}\text { kWp } \\
\text { (onboard) }\end{array}$ & La & $\mathbf{L i}$ \\
\hline 1 & 4 & 18 & 13.42 & 4.3 & 1.61 & 0.39 & 0.14 \\
\hline 3 & 4 & 42 & 26.85 & 9.8 & 1.61 & 0.87 & 0.28 \\
\hline 7 & 4 & 15 & 10.74 & 3.3 & 1.61 & 0.33 & 0.12 \\
\hline
\end{tabular}

*La: Lead acid battery; **Li: Lithium battery.

Table 4: Weight and cost of solar canoe components.

\begin{tabular}{|l|c|c|}
\hline \multicolumn{1}{|c|}{ Component } & Kilograms & Unit cost \\
\hline Lead-acid battery $(12 \mathrm{~V}-250 \mathrm{Ah})$ & 60 & $1.08 \$ / \mathrm{Ah}$ \\
\hline Lithium-Ion battery $(25.9 \mathrm{~V}-104 \mathrm{Ah})$ & 25 & $25.43 \$ / \mathrm{Ah}$ \\
\hline Solar panel $(30 \mathrm{~V}-230 \mathrm{~W})$ & 20 & $\$ 725$ \\
\hline Electric motor $(48 \mathrm{~V}-4 \mathrm{~kW})$ & 19.4 & $\$ 3,809$ \\
\hline Regulator $(48 \mathrm{~V}-4850 \mathrm{~W}-85 \mathrm{~A})$ & 4.2 & $\$ 600$ \\
\hline Medium size canoe (fiberglass) & 400 & $\$ 4,000$ \\
\hline & Total cost $(\mathbf{L a})$ & $\mathbf{\$ 2 3 , 8 0 4}$ \\
\hline & Total cost $(\mathbf{L} \boldsymbol{i})$ & $\mathbf{\$ 3 5 , 4 0 8}$ \\
\hline
\end{tabular}




\subsection{Economic analysis}

To perform an economic analysis to replace the existing outboard motor by an electric one, the cost of investment and operation of the two types of boats was estimated based on the interviews, the existing literature and the data collection from the field research (Table 5).

Based on the information presented in Table 5, the economic analysis results (net present value - NPV and payback period) are shown considering an interest rate of $5 \%$ for a 20 year period (Table 6).

Table 5: $\quad$ Estimated cost for traditional vs. solar electric 12-meter canoe.

\begin{tabular}{|c|c|c|c|}
\hline & Route 1 & Route 3 & Route 7 \\
\hline Time of traveling $(\mathrm{h})$ & 4 & 9 & 3 \\
\hline \multicolumn{4}{|c|}{ Traditional canoe } \\
\hline $\begin{array}{l}\text { Investment outboard motor 13hp } \\
\text { every } 6 \text { years }(\$)\end{array}$ & $\$ 1,030.00$ & $\$ 1,030.00$ & $\$ 1,030.00$ \\
\hline Fuel (\$/year) & $\$ 1,929.78$ & $\$ 4,342.00$ & $\$ 1,447.33$ \\
\hline Canoe Investment every 4 years $(\$)$ & $\$ 600.00$ & $\$ 600.00$ & $\$ 600.00$ \\
\hline Maintenance (\$/year) & $\$ 200.00$ & $\$ 200.00$ & $\$ 200.00$ \\
\hline $\begin{array}{l}\text { Estimated annual reduction of } \mathrm{CO}_{2} \\
2.38 \mathrm{~kg} \text { of } \mathrm{CO}_{2} \text { per liter of gasoline } \\
{[10]}\end{array}$ & 8.29 Ton & 18.65 Ton & 6.21 Ton \\
\hline \multicolumn{4}{|c|}{ Solar electric canoe } \\
\hline Investment outboard motor $4 \mathrm{~kW}(\$)$ & $\$ 3,809.00$ & $\$ 3,809.00$ & $\$ 3,809.00$ \\
\hline Investment $12 \mathrm{~m}$ fiberglass canoe $(\$)$ & $\$ 4,000.00$ & $\$ 4,000.00$ & $\$ 4,000.00$ \\
\hline Cost of Li-battery every 9 years $(\$)$ & $\$ 13,225.00$ & $\$ 26,450.00$ & $\$ 10,580.00$ \\
\hline Cost of La-battery every 4 years $(\$)$ & $\$ 1,623.60$ & $\$ 3,788.40$ & $\$ 1,353.00$ \\
\hline Electricity cost - PV system (\$) & $\$ 14,375.00$ & $\$ 31,050.00$ & $\$ 10,750.00$ \\
\hline Maintenance (\$/year) & $\$ 200.00$ & $\$ 200.00$ & $\$ 200.00$ \\
\hline
\end{tabular}

Table 6: Economic feasibility of solar canoes.

\begin{tabular}{|l|c|c|c|}
\hline \multicolumn{1}{|c|}{ Results } & Route 1 & Route 3 & Route 7 \\
\hline NPV (traditional canoe) & $\$ 31,228.00$ & $\$ 61,289.60$ & $\$ 25,215.61$ \\
\hline NPV (solar canoe with La-battery) & $\$ 28,277.89$ & $\$ 52,000.07$ & $\$ 23,772.00$ \\
\hline NPV (solar canoe with Li-battery) & $\$ 49,320.88$ & $\$ 92,324.24$ & $\$ 40,430.21$ \\
\hline Payback period (traditional canoe) & 11.6 years & $>30$ years & 6 years \\
\hline Payback period (solar canoe, Li-battery) & 12 years & 18.9 years & 7.6 years \\
\hline Payback period (solar canoe, La-battery) & 6 years & 8.5 years & 4.1 years \\
\hline
\end{tabular}




\section{Discussion}

Considering the long travel times of the proposed routes, it is recommended to locate recharge centers along the routes since it will reduce the number of batteries and solar photovoltaic panels required on board for autonomy. This will also have an effect on reducing weight on board and increasing the space in the boat for more cargo and passenger loads. Less weight also reduces propeller power consumption (see section 3.3) which leads to lower system costs. The battery-charging centers will be placed in strategic locations (as shown in Figure 1). These centers were established by balancing the energy consumption of the canoe, traveling at a given motor speed, the capacity of the batteries and solar photovoltaic generation on board.

For the routes with travel times of 4 and 3 hours, $42 \mathrm{~km}$ and $30 \mathrm{~km}$, respectively, at speed of $10 \mathrm{~km} / \mathrm{h}$, it is possible to travel with the boat configuration presented in table 3 , and recharge centers should be located at the beginning and end of the routes. For the longest route $(92 \mathrm{~km}, 9$ hours) there are two alternatives: using a single battery bank for the whole way, with the attendant problems of weight and space already described, or placing charging centers in strategic spots (Figure 1) and therefore reducing the number of batteries and solar panels required on board.

Along the routes analyzed in this study there are communities that are beneficiaries of Yantsa Ii Etsari Project. The solar boats might also serve as a means of transport to Centrosur technicians so they can follow up the PVS installed.

\section{Conclusions}

The selection of the best alternative depends mainly on the cost of the batteries, the type of boat and the route to cover. The proposal would be economically viable for either lead-acid or lithium batteries in fiberglass boats with navigation time between 3 and 4 hours. In any case, the boat operator would recover his investment through the values collected during the transport service (and by gasoline savings).

From the economic point of view, the lead-acid battery is the best option but for technical reasons lithium-battery is better since its energy density $(\mathrm{kWh} / \mathrm{kg})$ is higher. The energy density variable has a great impact on propeller power since it is related to the total weight of the boat.

This study has shown that the electric-solar canoe provides economic, social and environmental benefits, becoming a sustainable alternative for river transport in the Ecuadorian Amazon.

\section{Acknowledgements}

This research was supported by a grant from the Dr. Hermann Eiselen Doctoral Program of the Foundation Fiat Panis and German Academic Exchange Program (DAAD). The authors thank Empresa Eléctrica Regional Centrosur (agreement 
Centrosur - Universidad de Cuenca) for the information and support during field visits to the Yantsa Ii Etsari project.

\section{References}

[1] J. Jara-Alvear, D. Callo-Concha, and M. Denich, Decentralized rural electrification projects with solar home systems in the Ecuadorian Amazon: a holistic analysis. 1st International Congress and Scientific Expo ISEREE 2013, pp. 1-8, 2013.

[2] A. Morachevskii, Works of Academician B.S. Jacobi in the Field of Applied Chemistry. Russ. J. Appl. Chem., vol. 74, no. 8, pp. 1422-1425, 2001.

[3] Sun21, www.transatlantic21.org

[4] MC Turanor, www.planetsolar.org [online]. Available: papers2:// publication/uuid/A21231DA-CB4F-45BE-B0D8-582DBDA77C68.

[5] J. Jara-Alvear, H. Pastor, E. Calderon, M. Casafont, E. Araujo, and J. Garcia, Embarcaciones solares, una evolución al transporte marino en las islas Galápagos, Ecuador, 2013.

[6] A. Del Pizzo, R. M. Polito, R. Rizzo, and P. Tricoli, Design criteria of onboard propulsion for hybrid electric boats. 19th Int. Conf. Electr. Mach. ICEM 2010, 2010.

[7] V. Bertram, Ship propulsion (Chapter 6). Ship Design for Efficiency and Economy $2^{\text {nd }}$ edition, Butterworth-Heinemann: Oxford, pp. 180-205, 1998.

[8] P. Gutelle, The Design of Sailing Yachts book. Intl Marine Pub Co, 1984.

[9] TORQEEDO,www.torqeedo.com/en/technology-and-environment/ performance-and-efficiency.html

[10] CONELEC, Solar radiation map of Ecuador for power generation, 2008.

[11] Oficina Catalana del Canví Climátic, Guia práctica para el cálculo de emisiones de gases de efecto invernadero, 2012. 